\title{
GEOGRAFIJA - PROSTORSKI KONCEPT IN PLANIRANJE
}

\author{
Andrej Černe *
}

Izvleček

UDK $911: 711=863$

Članek je namenjen razmišljanju o geografiji kot znanosti, njeni konceptualni prostorski zasnovi, geografskemu vidiku ter geografskim metodološkim izhodiščem, ki tvorijo temeljno podlago za njeno tvorno vključevanje v različna področja planiranja.

Ključne besede: Geografski pristop, prostorski koncept, prostorsko planiranje.

$$
\text { GEOGRAPHY - A SPATIAL CONCEPT AND PLANNING }
$$

\section{Abstract}

The purpose of this paper is to present certain considerations about geography as a science, its conceptual and spatial plans, the geographical aspect, and the geographical methodology which form a basis for an active role of geography in the various fields of planning.

Key words: Geographical approach; Spatial concept; Spatial planning.

" Dr., izr. prof., Oddelek za geografijo, Filozofska fakulteta Univerze v Ljubljani, Aškerčeva 2, SI 1000 Ljubljana, Slovenija 


\section{GEOGRAFSKI PRISTOP}

Geografa spoznamo med drugim ne samo po tem, kaj proučuje, marveč tudi po tem, kako proučuje. Pri proučevanju družbe deli geograf skupne interese $\mathrm{z}$ drugimi znanstvenimi disciplinami, vendar $\mathrm{z}$ drugačnega zornega kota oziroma vidika. $\mathrm{Z}$ drugimi besedami, ekonomisti in geografi si zastavljajo različna vprašanja glede istih pojavov. Eno temeljnih izhodišč geografskega pristopa je $\mathrm{v}$ tem, da je prostorski. Geografe zanimajo vprašanja, na kakšen način so človekove dejavnosti razporejene in urejene na zemeljskem površju in kateri procesi so vodili $\mathrm{k}$ taki prostorski razporeditvi, ter seveda kako to vpliva na spreminjanje funkcije in podobe pokrajine.

Organiziranje človekovih dejavnosti z namenom zadovoljevanja potreb družbe je v nekem nasprotju $\mathrm{z}$ razmeroma skromnimi naravnimi in ostalimi dobrinami, ki nam jih nudi narava sama. V bistvu gre za tisto, kar so ekonomisti 19. stoletja imenovali "parsimonija narave". Narava je z vidika zadovoljevanja številnih človekovih potreb "skopa", saj lahko le manjši del teh potreb zadovoljujemo neposredno z naravnimi viri. Preskrba z "naravnimi viri" je brez dvoma ena izmed temeljnih in hkrati tudi najbolj kritičnih postavk razvoja družbenega sistema, čeprav se je družba vedno soočala in se bo še $v$ večji meri tudi $v$ prihodnosti s temeljnimi vprašanji omejitev prostora, časa, virov in znanja. Ravno na področju prostorskega razvoja mora družba pokazati vse svoje znanje in spretnosti, da bo ustvarila tak sistem, ki bo omogočal racionalno in smotrno rabo prostora kot omejene dobrine, ter "skopih" naravnih virov ter vseh ostalih razvojnih potencialov. Pod temi pogoji postaja sistem mnogo bolj kompleksen in zapleten, saj se omejenost in redkost dobrin pojavljata tako v razmerju človeka do narave, kot v razmerju do človekovih potreb in želja. Zapletena razmerja med gospodarskim, socialnim in prostorskim razvojem se kažejo tako na globalni, mednarodnih in regionalnih, kot na čisto lokalnih ravneh.

Bilo bi napak, če bi mislili, da imajo vsi geografi glede tega enotno, skupno stališče. Stališča geografije so se spreminjala. Razlike so obstajale in tudi obstajajo, ne nazadnje zaradi različnih filozofskih in metodoloških pogledov in pristopov. Skozi razvoj geografije od srede 19. stoletja pa vse do druge polovice 20 . stoletja pa vendarle lahko izluščimo nek skupni osrednji predmet zanimanja geografov, ki se v temeljih razlikuje od drugih družboslovnih in humanističnih ved. To osrednje področje zanimanja se nanaša na prostor kot tak, čeprav je ta izraz prišel v splošno, široko uporabo šele $v$ zadnjih desetletjih.

Prejšnje generacije geografov so namesto "prostor" bolj uporabljale izraze kot so: območje, regija, kraj, pokrajina, čeprav ti izrazi niso resnično pravi sinonim za prostor "per se". Lahko pa bi rekli, da so neka posebna oblika ali vidik prostora. 
Geografija ima številne in različne obraze, vsak od njih pa vendarle povuarja prostorska razmerja. Ekonomska geografija proučuje učinke naravnih in družbenih dejavnikov geografskega okolja na dejavnike proizvodnje, potrošnje in menjave; socialna geografija proučuje prostorske vplive na vzorce socialnih odnosov; politično geografijo zanimajo učinki lokacije na politična dejanja.

Za geografa je temeljnega pomena to, da imajo vse človekove dejavnosti prostorsko komponento oziroma razsežnost. Za proizvodnjo in potrošnjo je značilna prostorska dispariteta. Vse dejavnosti so tudi takšni ali drugačni "porabniki" prostora, in sicer ne glede na to, ali gre za kmetijsko proizvodnjo na 100 ha površin ali za tovarno na 200 $\mathrm{m} 2$. Tudi človek sam je "porabnik" prostora $v$ katerem živi. Menjava proizvodov in storitev zahteva neko obliko gibanja, in za premagovanje razdalj $\mathrm{v}$ prostoru potrebujemo čas, energijo in denar. Družbeni sistem ima torej prostorsko razsežnost, ki je primarno področje zanimanja geografov. Berry (1964) celo trdi, da je geografski vidik prostorski vidik. Geografija je bila v njeni otroški dobi obremenjena s številnimi informacijami o razporeditvi pojavov in procesov na zemeljskem površju. Namen in bistvo geografije je bil v prikazu prostorske razporeditve naravnih virov, proizvodnje in potrošnje itd. Tak pristop je velikokrat vodil tudi v prepričanje, da so vsi geografski pojavi enkratni in, da so posploševanje, sinteza in teorija nepomembni oziroma $v$ skrajnosti celo nemogoči. Zato je bila $v$ tridesetih in petdesetih let osrednja pozornost geografije usmerjena $\mathrm{v}$ tisto kar je Hartshorne (1939) imenoval "teritorialno (prostorsko) razlikovanje". Pomembne so bile razlike med kraji, pojavi in procesi na zemeljskem površju, ne pa skupne poteze. Nezadovoljstvo $s$ takim pristopom je koncem petdesetih let vodilo $\mathrm{k}$ temeljnim spremembam. Za takratno vzdušje je tipična kritika tega pristopa, ki jo je zapisal Ballaboan (1974): “....geografija potrebuje večjo trdnost pri določanju konceptov, večjo natančnost pri meritvah, aplikativnost pri sklepih .....". Lahko bi rekli, da je bila geografija, za razliko od drugih ved "šibka v teoriji a močna $v$ dejstvih".

V razvoju geografije je zaznati velik napredek od proučevanja, kje in kako so pojavi in procesi razporejeni na zemeljskem površju, $k$ bolj splošnim vprašanjem, zakaj so ti pojavi razporejeni in organizirani na zemeljskem površju tako kot so in ne drugače. Geografijo ne zanimajo samo vprašanja o tem, kje je kaj v prostoru in kakšno je, marveč predvsem, zakaj je tam, kako se je to zgodilo, kakšne so posledice in ne nazadnje, kako ravnati v bodoče. Geografi pri tem niso usmerjeni zgolj v "prostorski vzorec", marveč predvsem v proučevanje pojavov in procesov, ki so privedli do takega prostorskega vzorca in posledic le-tega. Pri tem se soočajo s temeljnim problemom, ki izhaja iz dejstva, da imajo vsi ekonomski pojavi vedno določen prostorski vzorec, vzroki oziroma procesi, ki so privedli da takega prostorskega vzorca, pa seveda niso vedno in edino prostorski. Zato tudi ne moremo pričakovati, da bi geografi našli odgovore na vsa prostorske probleme samo v prostorskem smislu. 


\section{GEOGRAFIJA IN PROSTORSKI KONCEPT}

Geografija uporablja tako absolutni kot relativni prostorski koncept. Hartshorne (1939) je celo trdil, da bi morali geografijo obravnavati kot horološko vedo, torej vedo o razporeditvi geografskih elementov v prostoru. S tega vidika so prostor upoštevali kot poligon za nameščanje človekovih dejavnosti v prostoru. Geografija kot "primerjalna korelacijska disciplina" naj bi uporabljala karte za medsebojne primerjave in spoznavanje "funkcijske integracije pojavov in procesov" v prostoru. Številni so ugovarjali takim stališčem o enkratnosti pojavov in procesov in poudarjali, da so "za geografijo pomembna samo prostorska razmerja". Omenjena razmišljanja so imela pomemben vpliv na razvoj bolj formalne prostorske znanosti. Šele v poznih 40 . in zgodnjih 50. letih je prostorski koncept postal del moderne geografske znanosti.

Številni geografi so prostor obravnavali, čeprav seveda ne enotno, kot "temeljni organizacijski koncept za geografijo". Blaut (1961) je ločil absolutni prostorski koncept, kjer je prostor "predvsem jasna fizična stvarnost ali empirična celota oziroma bistvo samo po sebi". Relativni prostorski koncept pa obravnava prostor zgolj kot "razmerja med pojavi in procesi ali zgolj kot prostorski vidik teh pojavov in procesov". Zato je prostor podvržen času in procesu. Ločevanje absolutnega in relativnega prostora je bilo samo po sebi izredno pomembno za razvoj splošnih teoremov prostorske organizacije. Če je namen geografije namreč v posploševanju (generalizaciji), potem mora geografija spoznanja o skupnih značilostih prostora utemeljevati s posameznimi primeri pojavov in procesov. Zaradi tega mora geografija uporabljati relativni koncept prostora. $\mathrm{V}$ stvarnosti moramo oba koncepta obravnavati skupno: prostorske strukture stvarnega sveta so preprosto začasni procesi, ki pa imajo dolgoročen pomen. Številni geografi so se pridružili tem razpravam in obravnavali geografijo predvsem v morfološkem smislu. Pri tem so ohranjali tisto, kar je Sack (1980) kasneje opredelil kot "prostorski separatizem". V bistvu so številni posamezniki seveda že pred tem trdili, da geografija ne more temeljiti zgolj na geometriji. Za fizično znanost in čisto fizične procese, ki jih proučujejo tudi geografi, je bila in je geometrija prostora žal pogostoma tudi geometrija razlage. Pri razlagi človekovega obnašanja v prostoru, njegovega odnosa do prostora pa dejstva, ki se nanašajo samo na geometrične značilnosti prostora, niso najbolj primeren in ustrezen način razlage. Ravno v tem obdobju je napredek pri razvoju metod znotraj prostorskih analiz pomembneje vplival na razmerja med geografijo in modeli prostorske organizacije. Številne tehnike za opredeljevanje prostorskega vzorca in prostorskega časovnega napovedovanja so omogočile spoznanja o nekaterih pravilnostih razporeditve pojavov in procesov v prostoru. Kakršna koli razlaga prostorskih struktur pa mora biti seveda zaobsežena tudi v negeometričnem smislu. 
Prostorske analize predstavljajo kvantitativni postopek pri lokacijskih analizah. Pojem so uporabljali tudi kot sinonim za same lokacijske analize. Prostorske analize vsebujejo proučevanje treh medsebojno povezanih vsebin: prostorske organizacije, prostorsko-časovnih procesov in napovedovanje bodočega prostorskega razvoja. S prostorsko organizacijo razumemo prostorske značilnosti razporeditve pojavov in procesov v pokrajini: lego, položaj, (absolutno in relativno lokacijo) zunanjo podobo naselij, prometnic, industrijskih obratov itd. Prostorski analitiki so praviloma opredeljevali te pojave $v$ obliki točk, linij in območij (arealov) in pri tem poudarjali predvsem geometrične oziroma morfološke značilnosti teh pojavov. Unwin (1981) je označil prostorske analize za raziskave o razporeditvi točk, linij, območij in površja na kartah (analize prostorskih vzorcev). Tako sta sistemizacija in klasifikacija pri morfometričnih analizah zgrajeni na podlagi geometričnega, prostorskega koordinatnega sistema. Prostorska razporeditev naselij upošteva naselja kot točke v prostoru, kar pomeni, da zanemarja njihovo velikost in funkcije. To pa vendarle omogoča analizo omrežij in raziskave na področju oblik in prostorskih značilnosti razporeditve naselij. Morfometrične analize torej lahko vodijo k določenim tipom prediktivnih in simulacijskih modelov. S poznavanjem geometričnih pravil teorije o centralnih naseljih, gostote prebivalstva in velikosti ter lokacije dveh centralnih naseljih je možno "napovedati" ostala naselja $v$ sistemu centralnih naselij. V ekstremnih primerih je to pomenilo, da so geografi posvečali pozornost predvsem prostorski razporeditvi pojavov $v$ pokrajini, ne pa samim pojavom. Čeprav le malo geografov uporablja tehnike, ki so bile razvite za potrebe splošnih linearnih modelov, pa vendarle številni zagovarjajo stališče, da vsebuje prostorska analiza predvsem reševanje statističnih problemov, ki se $\mathrm{v}$ večji meri nanašajo na opredeljevanje metod in postopkov, ki so namenjeni analizam številčnih podatkov.

Prostorske analize so tesno povezane s pozitivistično razlago $v$ geografiji, saj gre pri njih najpogosteje za formalne modele prostorske organizacije in upoštevanje predpostavk in stvarnega poznavanja prostorske organizacije (ureditve) in prostorskočasovnih procesov. Do neke mere kot reakcija napram takemu načinu razlag pa je pri tako imenovanem humanističnemu vidiku $v$ ospredju manj formalen pristop pri proučevanju organizacije človekovih dejavnosti v prostoru. Strukturalisti dodatno pojasnjujejo, da mora biti naše proučevanje $v$ večji meri usmerjeno ne toliko v stvarno prostorsko zgradbo kot proces, marveč moramo gledati na "globjo zgradbo" ki je podlaga človekovim dejavnostim in njihovim razmerjem. Tako humanisti kot strukturalisti imajo odklonilen odnos do "geometrične konfiguracije človekovih dejavnosti na zemeljskem površju". Humanisti zaradi tega, ker prostorske analize negirajo človekov "živi svet" izkušenj in pomen okolja za človeka. Poleg tega so ljudje v prostorskih analizah upoštevani kot stvari, ki pa imajo enkratne izkušnje in določen odnos do prostora, $v$ katerem živijo. Strukturalisti pa so nezaupljivi do prostorskih analiz zato, ker opisujejo samo navidezno ali "površinsko" zgradbo, ne pa razmerij, ki so bistvena za družbo kot celoto. 
Vprašanja, ki si jih geografi zastavljajo o lokacijah, gibanju prebivalstva, krajih, naseljih, so vprašanja o dogodkih $v$ primarnem, fizičnem prostoru. Analize prostorskega vzorca točk, prostorska avtokorelacija in prostorska difuzija so izražene v preprosti Evklidovi geometriji. Geografske razlage lahko vsebujejo geometrične lastnosti prostorske razporeditve pojavov in procesov, ne smejo in ne morejo pa biti zasnovane zgolj na njih.

Geometričnim razmerjem moramo pripisati gospodarski, socialni, prostorski, fizični, naravni ali biološki pomen, predno postanejo lahko pojasnjevalna. Čeprav je lahko geometrija pomembno orodje pri geografskih raziskavah, ne more predstavljati teoretičnega okvira, ker je geometrična analogija $\mathrm{z}$ geografskimi pojavi in procesi zasnovana skozi določene logične strukture in ne skozi pojasnjevalno dedukcijo (Human Geography, 1994). "Problem slabše konceptualizacije prostora je bil rešen z upoštevanjem prostora skozi družbeno prakso. Z drugimi besedami: ne obstajajo odgovori na filozofska vprašanja, ki izhajajo iz narave prostora - odgovori leže $\mathrm{v}$ družbeni praksi. Vprašanje, kaj je prostor, je potrebno nadomestiti z vprašanjem: kako to, da različne družbene prakse ustvarjajo in uporabljajo različne koncepte prostora" (Sack, 1980). To pa narekuje oziroma zahteva tisto, kar je Harvey (1969) poimenoval "pogled prostorskega razmerja", v katerem je prostor zaobsežen $\mathrm{v}$ predmetih le, $\mathrm{v}$ kolikor predmet vsebuje in predstavlja znotraj samega sebe razmerja do drugih predmetov. Taka opredelitev pomeni združevanje dveh osnovnih načel: objektivnega prostora (stvarnega, fizičnega) in družbenega (socialnega) prostora. Pri vsakem poskusu raziskovanja družbenega prostora je potrebno izhajati ne iz "predmetov v prostoru", marveč iz proučevanja ustvarjanja prostora za človekov obstoj, znotraj katerega se lahko odvija družbena praksa. Analize družbenega prostora niso bile osredotočene na abstraktno geometrijo, marveč na razmerja med različnimi skupinami prebivalstva in njihovimi značilnostmi, ki se izražajo, ter so delno tudi določena skozi njihovo prostorsko razporeditvijo: kraje, regije in pokrajine (Gregory, 1993).

\section{GEOGRAFIJA IN PLANIRANJE}

Tudi področje planiranja moramo obravnavati znotraj splošnih konceptov. Vedeti moramo namreč, kakšen pojav moramo proučevati, katera vprašanja si moramo zastavljati in, kakšna filozofska stališča morajo usmerjati naše raziskave. Planiranje potrebuje omejitve in samo konceptualna definicija lahko take omejitve tudi omogoča.

Planiranje ima časovno, geografsko, funkcijsko in institucionalno razsežnost (Heide, 1992). Časovna razsežnost izhaja iz usmerjenosti planiranja v prihodnost. V planerskem procesu gre za neko obliko kontinuirane poti, ki se začne v sedanjosti in 
nadaljuje $v$ možne prihodnosti. Planiranje je dejavnost, ki je usmerjena v prihodnost, iz preteklosti pa izbira tiste elemente in dejavnike, ki so temeljnega pomena za analiziranje obstoječih pogojev nadaljnega razvoja oziroma za opredeljevanje možnih in zaželjenih sprememb ter, kako do teh sprememb priti (Friedmann, 1987). Planiranje je usmerjeno $\mathrm{k}$ pogledom $\mathrm{v}$ preteklost zaradi skupne zgodovine in $\mathrm{v}$ prihodnost zaradi skupne usode. Vse znanje, pridobljeno z uporabo znanstvenih metod proučevanja, je več ali manj znanje o preteklih dogodkih. Planerji potrebujejo seveda nekaj vedenja tudi o prihodnjih dogodkih, zato se ukvarjajo tudi z napovedovanjem in projekcijami oziroma snovanjem prihodnosti glede na želje in razvojne možnosti. Vprašanje je seveda, katere predpostavke pri tem upoštevati, posebno v obdobjih hitrih strukturnih sprememb, in sicer zaradi zahtev in potreb, da bi to znanje o preteklosti uporabili tudi kot primerno znanje za poznavanje prihodnosti. Preteklost lahko spoznamo, prihodnost pa si lahko le zamišljamo.

Prostor kot fizična stvarnost je "materialni predmet planiranja". Odločanje o "posegih v prostor" pa je "formalni predmet planiranja". Končni namen planiranja je seveda v vplivanju na spremembe materialnega predmeta - prostora. Poudarjanje pozornosti na formalni predmet planiranja je temeljni korak pri planiranju: plani niso "načrti na papirju" marveč temeljni okviri za sprejemanje odločitev.

Osrednji predmet prostorskega planiranja (s predmetom mislimo na predmet planiranja oziroma bolje na tisto, kar se planira) je izrazito prostorski. Opravka imamo seveda s številnimi tipi planiranja, ki so "prostorski". Prostorski pa so vendarle samo v tem smislu, da jih zanima prostorska organizacija dejavnosti na zemeljskem površju. Za prostorsko planiranje pa sta značilni več-razsežnost (multidimenzionalnost) in več-ciljnost. Prostorsko planiranje se ukvarja namreč s prostorskimi vplivi številnih in različnih razvojnih dejavnikov. To je tisto, kar ločuje prostorsko planiranje od številnih drugih oblik planiranja, katerih pristop bi lahko na splošno označili kot planiranje s prostorsko komponento.

Prostorsko planiranje zanimajo seveda tisti procesi, ki se nanašajo na prostor. Besedo prostor uporabljamo $\mathrm{v}$ njegovem najširšem pomenu, saj ni omejena samo na trodimenzionalno prostorsko evklidovo geometrijo, marveč se nanaša tudi na ekonomski prostor (stroške premagovanja razdalj $\mathrm{v}$ prostoru) ali psihološki in zaznavni prostor. Najpogosteje zanima prostorske planerje prostorska razsežnost gospodarstva in družbe kot celote. Še prav posebej jih zanimajo prostorska razmerja med socialnimi in gospodarskimi dejavnostmi oziroma struktura prostora, kjer se te dejavnosti odvijajo. Planerji morajo poznati velikost in lokacijo gospodarskega prostora, kakor tudi njegove funkcije oziroma prostorska razmerja med dejavnostmi. Ne glede na to, kako je stvarni prostor lahko popačen zaradi ekonomskih ali psiholoških dejavnikov, mora biti osrednji predmet zanimanja prostorskih planerjev proučevanje medsebojnih prostorskih razmerij v stvarnem (geografskem) prostoru. 
Predmet prostorskega planiranja je seveda zemljišče kot prostorska enota. Njena relativna lokacija je opredeljena s človeškimi in/ali naravnimi dejavniki, ki povezujejo zemljišča med seboj v različne prostorske razsežnosti od parcele, lokacije, območja, do sveta kot takega. Prostorsko planiranje je zato neposredno povezano s funkcijsko razsežnostjo planiranja. Zemljišča služijo hkrati različnim funkcijam, imajo lahko različne lastnike in/ali uporabnike, ki imajo velikokrat zelo različne interese glede enega in istega zemljišča. To pa vodi v vprašanja o reševanju oziroma usmerjanju in urejanju teh konfliktov oziroma $\mathrm{k}$ institucionalni razsežnosti planiranja. $\mathrm{Ob}$ tem pa je potrebno še posebej poudariti, da imamo opravka s spremembami. Kvaliteta zemljišč se seveda spreminja, poleg tega se spreminja tudi njena relativna lokacija in končno se spreminja tudi njihova geografska razsežnost. Gre za konceptualizacijo predmeta planiranja, strukture prostora in prostorskih razmerij, ki poteka tudi skozi institucionalne okvirje. To daje neke vrste drugačen pogled na domeno prostorskega planiranja kot na dejavnost za reševanje vseh vrst razvojnih vprašanj.

Prostorsko planiranje uporablja splošne metode planiranja za izdelavo prostorske zasnove bodočega razvoja. Zaradi tega je prostorsko planiranje usmerjeno v veliki meri k procesom, ne pa $\mathrm{k}$ izdelavi enega plana ali plana končnega stanja. Njen pravi predmet proučevanja je pravzaprav tisti del geografije, ki proučuje urbane in regionalne sisteme.

Prostorsko planiranje predstavlja danes le manjši del planiranja in tudi na tem področju je tradicija "fizičnega planiranja" $v$ večji meri nadomeščena $\mathrm{z}$ znanstveno zasnovanimi analizami, ki vsebujejo modeliranje, projekcije in prostorske sinteze, vključno $\mathrm{z}$ opredeljevanjem njihovih razvojnih vplivov in posledic. Prostorsko planiranje se ukvarja z vprašanji prostorskega nameščanja razvoja, ne s splošnim preprečevanjem tega razvoja, vendar ob spoznanju, da ima prostor oziroma naše fizično okolje omejene sposobnosti za nameščanje razvoja kot rasti. Bilo bi zelo nevarno, če bi se prostorsko planiranje ločilo oziroma odmaknilo od razvojnih interesov. To stališče lahko soočimo s tako razvpitim pojmom kot je "sustainability". Pogosto je namreč koncept trajno uravnoteženega razvoja povezan $\mathrm{z}$ doseganjem ciljev na področju varstva narave, naravnih virov, okolja itd. Vendar pa je potrebno pvdariti, da je bistvo trajno uravnoteženega razvoja ravno $v$ integraciji teh ciljev $s$ prostorskim razvojem, ne pa $v$ njihovem ločevanju. Kljub temu, da je koncept o trajno uravnoteženem razvoju star že več kot 10 let, je šele Brundtlandova komisija zavrnila argumente o tem, da se gospodarski razvoj in kvaliteta okolja izključujeta. Za trajno uravnotežen razvoj je temeljnega pomena dolgoročno vzdrževanje vsesplošne kvalitete življenja, ohranjanje trajnega dostopa do naravnih virov in izogibanje trajne degradacije okolja (WCED, 1987)

Moderna planerska praksa je družben in političen proces, $v$ katerem številni dejavniki, ki predstavljajo številne različne interese, sodelujejo $\mathrm{v}$ jasni delitvi dela. Planerska praksa $\vee$ modernem pomenu besede se je začela $v$ prvih desetletjih tega stoletja, 
čeprav segajo njene ideološke korenine v 18. stoletje. Planiranje kot oblika usmerjanja družbe izhaja iz Francije in Saint-Simonovih pristašev, posebno pa še Auguste Comta, katerega "znanost o družbi" naj bi po njegovem vodila svet po varni poti k družbenemu napredku.

Inženirji so bili prvi predstavniki znanstvenega planiranja. Na žalost so zapadli pod vpliv pozitivizma $v$ 19. stol., saj so precenjevali moč znanja. V tem so jih najprej prerasli, nato pa nadomestili geografi z njihovo "družbeno geografsko" tradicijo. Družbeni geografi niso bili sami očitni pozitivisti, marveč so bili tudi prepričani, da je planiranje neke vrste aplicirana geografija. Nekateri celo poskušajo dokazovati, da je prostorsko planiranje pravzaprav neke vrste aplicirana geografija. Številni seveda odločno nasprotujejo takim stališčem, čeprav hkrati tudi priznavajo oziroma poudarjajo pomen aplikativnosti geografskega znanja. Prostorsko planiranje mora brezpogojno vsebovati tudi številne druge vidike, ki pa jih ne najdemo znotraj geografije: pravna razmerja, gradbeništvo, arhitekturo. Med temi velja še prav posebej poudariti študij samega procesa planiranja, načine kako izvajati nadzor nad razvojem in kako ga usmerjati v tiste smeri, ki bodo služili doseganju človeških ciljev. Pri tem je potrebno podčrtati "fenomenološki" vidik, ne pa konvencionalni "pozitivistični" vidik znanja (Hall, 1992).

Pred 19. stoletjem so bile v prevladi zelo različne oblike planiranja. Ker je planiranje temeljilo več ali manj na geometričnem redu v prostoru, so tak pristop poimenovali "ortogonalna zasnova" (Hall, 1995). Za številne planerje so bile ravne linije in pravi koti klasični primeri racionalne urejenosti v prostoru. Prostorska zasnova je klicala k "pravilnemu (urejenemu) pristopu", v katerem so posamezne funkcije povezane med seboj $v$ prostoru tako, da je njihova logika postala vidna in ustvarjala koherenten sistem prostorskih razmerij (Houghton-Evans, 1980). Ortogonalna zasnova se je v prvi vrsti nanašala na fizično razporeditev dejavnosti $v$ dvo ali tridimenzionalnem prostoru, namenjena pa je bila statičnemu, hierarhičnemu svetu, ki je bil zgrajen kot del harmoničnega reda.

Prostorsko planiranje je bilo dolgo časa zelo podrobno in izčrpno, saj se je izražalo najpogosteje $v$ prostorski obliki natančnih dispozicij vseh vrst rabe prostora. Pristop v planiranju je bil zasnovan na podlagi "analize pred planom", ideje, ki je v glavnem prišla iz Nemčije, čeprav jo pripisujemo P.Geddesu. V večji meri so tudi geografi zagovarjali ta pristop. Prostorski plani so podrobno prikazovali prostorsko zasnovo nekega zaželjenega stanja $\mathrm{v}$ prihodnosti. Filozofija takega pristopa je bila osredotočena h konceptom priprave splošnega, generalnega ali "master" plana. Ideja, da morajo biti plani zasnovani na trdnih temeljih, na analizi pred planom, je vzbudila veliko pozornosti med planerji. Pomenila je eno izmed najbolj prepričevalnih planerskih načel prve polovice tega stoletja. Analiza je bila namenjena opredeljevanju stanja in obstoječih razvojnih teženj. Poleg opredeljevanja bodočega željenega razvoja, je bila na ravni analize obvezna tudi geografska sinteza. 
Planiranje v obliki "analiza pred planom" je temeljilo na stališču, da je planiranje stvar poznavanja “dejstev". Nastajali so plani kot kvazi-zakonski dokumenti, ki so v diagramatični obliki prikazovali bodočo rabo zemljišč. Sama regulativa pa naj bi zagotavljala učinkovitost planiranja. Implementacija planov je bila več ali manj stvar izvajanja plana.

Tudi samo planersko izobraževanje je bilo sprva namenjeno pripravi in izdelavi prostorskih planov, ne pa izobraževanju s področja planerskih metod. Prvi, ki so si sploh resneje zastavljali ta vprašanja, niso bili učitelji fizičnega, prostorskega planiranja, marveč učitelji na področju planiranja za potrebe industrijskih družb v ameriških poslovnih šolah (C. Bernard, P. Druker, H. Simon). Izobraževanje se je razvilo $v$ znanost o tem, na kakšen način priti do najboljših odločitev. Nova "filozofija" tako imenovanega“"podjetniškega planiranja" je pričela v 60. letih pomembneje vplivati na usmerjenost in vsebino izobraževanja na področju prostorskega planiranja

Stare ideje o planiranju kot o proizvodnji "načrtov na papirju" so prerasle v ideje o planiranju kot neskončnem kontinuiranem nadzoru razvoja. Opustitev deduktivnega pristopa je izhajala iz spoznanja o omejenosti človekovega znanja in problemih obvladovanja številnih informacij ter vlogi politične izbire pri opredeljevanju problemov. Nova razmišljanja so predstavljala neke vrste sistemski pristop $\mathrm{v}$ planiranju. Pristop je bil osredotočen v cilje plana in različne možne koncepte za doseganje teh ciljev. Vse to pa je bilo predstavljeno prej v pisni obliki, kot pa v obliki podrobnih tematskih kart. Poudarek je bil na iskanju možnih posledic alternativnih prostorskih konceptov za bodoči razvoj. Planersko delo se je pričelo z zasnovo ciljev razvoja. Analize so vodile v obsežne raziskave. Nato so sledili modeli rabe zemljišč, projekcije bodočih potreb, splošne alternative, vrednotenje itd. V 70. letih je pomenil racionalni vseobsežni pristop naslednje korake $\mathrm{v}$ planerskem procesu: zasnova ciljev, alternative, vrednotenje, izbor plana, program in izvajanje plana. $\mathrm{Na}$ področju analiz pa je planiranje sledilo trem stopnjam:

- opisni stopnji opredeljevanja problema, vključno $\mathrm{z}$ analizo celotnega območja;

- analitični stopnji raziskovanja medsebojnih razmerij in temeljnih razvojnih teženj;

- stopnji sintetiziranja spoznanj $\mathrm{v}$ koncepte kot podlage za zasnovo bodočih prostorskih struktur.

Inženirji niso poznali metod za združevanje in sintetiziranje različnih elementov $\mathrm{v}$ planu. Podobno kot arhitekti, so tudi inženirji razumeli zadnji korak pri zasnovi plana kot ustvarjalni napor (domislek), zato so ga prepuščali arhitektom, ki so opravili sintezo elementov v splošno prostorsko zasnovo. 
Urbanisti so vztrajali pri tem, da je planiranje sinteza, ki mora biti prežeta z vizijo. Vizija pa je sposobnost posameznikov. Številni so kritizirali tak pristop, češ, da je intuitivni pristop $\mathrm{k}$ družbenim problemom neustrezen, da so temeljne raziskave upoštevane več ali manj instrumentalno, da je v preveliki meri posvečena pozornost zgolj končnemu produktu, ne pa različnim možnostim prihodnjega razvoja. Številni planerji so gledali na planiranje kot na dejavnost, ki je namenjena zasnovi načrta za bodoči prostorski razvoj v prostorsko-fizični obliki. Planiranje naj torej vzpodbuja tak prostorski razvoj in upošteva taka merila za nadzor tega razvoja, ki bodo $\mathrm{v}$ kar največji meri zagotavljala izvedbo zaželjenega razvoja v prihodnosti. Zavedati pa se moramo, da prostorske oziroma fizične razsežnosti razvoja družbene skupnosti, ne glede na to kako jo opredeljujemo, ne moremo zaobseči in omejevati zgolj na raven prostorske predstavitve.

\section{LITERATURA}

- Blaut J., 1961: Space and Process Professional Geography, Vol. 13, str. 1-7.

- Friedmann J., 1992: Empowerment The Politics of Alternative Development. Blackwell, Oxford.

- Friedmann J., Weaver C., 1979: Territory and Function: The Evolution of Regional Planning. Edward Arnold, London.

- Gatrell A. C., 1983: Distance and Space. A geographical Perspective. Contemporary Problems in Geography. Claredon Press, Oxford.

- Gregory D., 1993: Geographical imaginations. Blackwell, Oxford.

- Hall P., 1995: Cities of Tomorrow. An Intelectual History of Urban Planning and Design in the Twentieth Century. Blackwell, Oxford.

- Hall P., 1992: Urban and Regional Planning. Peter Hall, Routledge, London.

- Hartshorne R., 1939: The Nature of Geography: A critical survey of current thought in the light of the past. Association of American Geographers, Lancaster.

- Harvey D., 1969: Explanation in Geography. Edward Arnold, Bristol.

- Heide H., 1992: Diagonal Planning: Potentials and Problems. Planning Theory Newsletter, Nr. 7/8, str. 135-134.

- Hougton-Evans W., 1980: Schematia in British New Town Planning V: Shaping an Urban World. Gordon Cherry, St.Martin's Press, New York, str. 101-128.

- Johnston R. J., 1980: On the Nature of Explanation in Human Geography, Trans. Inst. Br. Geogr., n.s. 5, str. 402-412.

- Lefebvre H., 1991 The Production of Space. Blackwell, Oxford.

- Pavlović B. U., 1978: Filozofija prirode. Naprijed, Zagreb.

- Sack R. D., 1980: Conceptions of Space in Social Thought. Minneapolis Univ. Press, Mcmillan, London. 
- World Commission on Environment and Development (WCED) (1987) Our Common Future (Brundtland Commission), Oxford Univ. Press, Oxford.

\section{GEOGRAPHY - A SPATIAL CONCEPT AND PLANNING}

\section{Summary}

From the mid-19th century until the second half of the 20th century, the central object of geographers' interest in the development of geography was space as such, although this specific term has penetrated into the general, widespread use only in the last few decades. It is of crucial importance for a geographer to assimilate a fact that all human activities comprise a spatial component or dimension.

A great progress can be noticed in the development of geography: from the study of where and how phenomena and processes are distributed on the Earth surface, to more general questions of why these phenomena are distributed and organized on the Earth surface as they are and not in some other way. Geography is not only interested in the questions of where in space is something and how it looks like but, above all, why it is there, how it happened, and of what kind the effects are and, last but not least, how to act in the future. However, geographers are not oriented into the "spatial model" only but, above all, into the study of phenomena and processes which have resulted in such spatial model, and the effects of the latter. In doing so, they have to face a basic problem proceeding from the fact that all phenomena and processes always follow a certain spatial pattern, while the causes and processes which have made this spatial pattern are not always, and not only spatial. Therefore, it can not be expected that geographers could find the answers to all spatial problems only in the sense of space.

The planning has a temporal, a geographical, a functional and an institutional dimensions (Heide, 1992). The temporal dimension proceeds from the planning orientation into the future. There is a certain form of continuous path in the planning, which starts in the present and continues into the possible futures. The planning is a future-oriented activity selecting from the past elements and factors which are of crucial importance for analysing the exisiting conditions of further development, or determining the possible and the desired changes, and finally it offers the method of how to effectuate these changes (Friedman, 1987). The planning is oriented via the aspects of the past due to the common history into the future because of the common destiny. All the knowledge acquired by using the scientific methods of research is, more or less, the comprehension of the past events. But the planning experts, moreover, need certain knowledge about the forthcoming events; therefore, they are concerned with prognoses and projections about the desired and the possible future 
development. There is a question, of course, which are the premises to be taken into consideration, especially in the period of fast structural changes, because of the requirements that a comprehension of the past would provide for the understanding of the future. Nevertheless, we can get acquainted with the past, but the future can only be anticipated.

A geographical dimension refers to space as such. To the actual space, to the space of geometrical or formal relations, to the four-dimensional space. The space as a physical reality is the "material object of planning". While deciding on the "interventions into the space" is the "formal object of planning". The final purpose of the planning is, of course, to influence the changes in this material object - the space. An emphasized calling of attention to the formal object of planning is a basic step in the planing: the plans are not "just the plans on the paper" but the basic frames for taking decisions.

The central object of spatial planing (the 'object' means the object of planning, or, that which is planned) is explicitly spatial. There are, of course, numerous types of planning, which are "spatial". However, they are spatial only in the sense of being interested only in the spatial organization of activities on the Earth surface. On the other hand, two elements are typical of spatial planning: multidimensionality and multipurpose character. The spatial planning, namely, deals with the spatial effects of numerous and diverse factors of development. This is the essence which represents distinction between the spatial planning and other forms of planning and the approach of which could generally be defined as the planning with a spatial component. 